\title{
GENDER AND WATER FROM A HUMAN RIGHTS PERSPECTIVE: THE ROLE OF CONTEXT IN TRANSLATING INTERNATIONAL NORMS INTO LOCAL ACTION
}

\section{Nandita Singh, Karsten Åström, Håkan Hydén and Per Wickenberg \\ Abstreack ]}

An important area in the discourse on gender and water is water supply where women are seen as the key actors and beneficiaries. A human rights approach to development has been adopted with access to safe water explicitly recognized as a basic human right. This right places a legal obligation upon governments to translate the international norms into practice. But does explicitly acknowledging the human right to water make a practical difference in women'slives? Using an actor-oriented perspective, this paper analyzes how the international legal norms for realization of the right get reconstructed in local communities where women are the right holders. The empirical data for the analysis will be drawen from a first-hand qualitativestudy in rural India. The findings of the study show how the socio-cultural matrix provides the environment for implementing the right and determines its equitable and effective exercise by women.

\section{IKeywora!s ]}

Human rights, gender, water, rural, social norms, cultural beliefs, India

\section{Received 5 March 2008 Accepted 6 May 2008}

\section{Introduction}

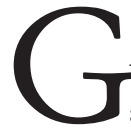

ender and water are linked in various ways, with roles, responsibilities, rights and privileges regarding water distributed differently between women and men. Out of the different water use domains, water supply is seen as specifically associated with women, who are traditionally and almost universally regarded as domestic water managers. Over the last few decades, their role has been attributed much dynamism, with an overwhelming emphasis on enhancing their involvement in the water sector from mere 'users' (beneficiaries) to 'managers' (actors), with increased choice and voice in the water management processes so that their access to and control over water resources can be strengthened.

Over the last three decades a global policy framework has emerged to increase the influence of women. The role of women as domestic water managers began to be officially recognised at the UN Water Conference, Mar del Plata, Argentina in 1977, prompting the UN to declare the decade of 19811990 as 'International drinking water supply and sanitation decade'. This has been followed by a move to promote women's participation in water resources management (ICF, 2001; ICWE, 1992; WWC, 2003).

These various international conferences have recognized water as a basic human need. Some have also gone further to affirm the right to water (UNESCO, 2006). The 1977 Mar del Plata Action Plan stated that all peoples have the right to have access to drinking water in quantities and of a quality equal to their basic needs (UNESCO, 2006). The recognition of water as a human right was mentioned in the Convention on Elimination of Discrimination against Women, (CEDAW, 1979) and the Convention on Rights of the Child, (CRC, 1989). However, despite the various global efforts, 1.1 billion people in the world continue to lack sustainable access to safe water for domestic and personal use (UNDP, 2003). Worst affected among these are women who continue to face hardships as domestic water users and managers.

Dr Nandita Singh is a social anthropologist at the Department of Land and Water Resources Engineering, Royal Institute of Technology (KTH), Stockholm, Sweden.

Professor Karsten Åström, Håkan Hydén and Associate Professor Per Wickenberg are at the Department of Sociology of Law, Sweden University, Lund, Sweden and research and teach in the areas of child/human rights in relation to environment, welfare legislation, and sustainable development. 
Consequently, the Millennium Development Goal (MDG) of halving the people without sustainable access to safe water by the year 2015 appears to be a formidable task. The right to water has been more explicitly and holistically recognized through adoption of General Comment No. 15 by the United Nations Committee on Economic, Social and Cultural Rights in 2002. The Committee emphasized the government's legal responsibility to fulfill the right and defined water as a social, cultural and economic good (UNESCO, 2006). The right to water has been recognized as a basic prerequisite for realization of several other human rights, including the fundamental rights to life food, self-determination, an adequate standard of living, housing, education, health, to take part in cultural life, to work and to be healthy (ECOSOC, 2002;.Scanlon et al. 2004; WHO 2003).

The human right to water entitles every woman and man to sufficient, safe, acceptable, physically accessible and affordable water for personal and domestic uses. The General Comment acknowledges that while the adequacy of water may vary according to different conditions, the factors of 'availability', 'quality', and 'accessibility' are universally applicable. The dimensions of the latter include physical accessibility and nondiscrimination among others (ECOSOC 2002).

In recognition of women's role as domestic water managers, special attention is to be paid within the scope of this declaration to women as 'a group traditionally facing difficulties in exercising the right' (ECOSOC 2002). In appreciation of the genderspecific human rights norms and standards that recognize equal rights of women and men (Tomasevski, 1993; Goonesekere, 2008), the General Comment lays down the obligation of States Parties to guarantee that the right is enjoyed by both without discrimination and on the basis of equality between men and women. The States Parties are obliged not only to take steps to remove any de facto discrimination on prohibited grounds that could impede enjoyment or exercise of the right to water; but also to give special attention to women as individuals / groups who have traditionally faced difficulties in exercising this right and to take steps to ensure that the disproportionate burden they bear in collection of water be alleviated.

\section{Water as a human right}

Explicitly recognizing water as a human right can have a significant impact on national water law, policy, advocacy and development programs. According to Jolly (1998), 'to emphasize the human right of access to drinking water does more than emphasize its importance ...it emphasizes the obligations of state parties to ensure access...'. Explicitly acknowledging a human right to water can help to place water issues higher up on political agendas around the world, helping to increase the pressure to translate the right into specific national and international legal obligations (UNESCO, 2006).

But going beyond the legal interpretation of the right and its claimed benefits, a number of critical questions concerning gender and water can be raised: Does explicitly acknowledging human right to water make a practical difference in women's lives as domestic water managers? Does implementation of action for promoting, protecting and fulfilling the right necessarily imply its effective realization for right-holders, especially the women? How does the cultural context of the local community where they are members influence the process of their enjoyment of the right?

According to the actor-oriented approach, which is based on the idea of 'social interfaces' where people interact, every situation is conceived of as an 'arena' in which the various actors (e.g., local groups within the community with different interests, outside groups that want to make use of the resource, departments within a government that may also be to some extent in competition with each other, and even individuals who have their own agenda) play out their struggle with whatever means they have at their disposal in order to reach their own goals. People are social actors that do not merely react to what happens around them, but also have the capacity to process social experience and respond accordingly (Long 1992). Because people and institutions, acting from diverse histories and life worlds, have different interpretations of situations and events, they develop differential responses to similar conditions and processes thereby changing the meaning of institutions and the course of events in unpredictable and multi-directional ways.

Different actors have different powers and different means, therefore the particular conditions 
and environment in which they occur have to be considered when identifying the actors (Skutsch, 1996). Actor-oriented studies on human rights practice contend that people live in a context of legal and cultural pluralism, and strategically draw from both their cultural and religious norms and formal rights regimes in dealing with real-life situations. Both cultural norms and formal rights regimes are argued to provide opportunities and challenges to the rightsholders in dealing with specific situations (Nyamu, 2000, Nyamu-Musembi, 2002, Nhalpo, 1995).

Drawing upon such a theoretical construct, the paper proposes the hypothesis that if the real concern lies with ensuring realization of the right to water by women, there is a need to move beyond the international and national levels of action regarding the human right to water to an analysis down at a 'third' level - one that is defined by the context of the society where local women as members are expected to realize their right. Using an actor-oriented perspective, the paper

\section{India: states and territories}

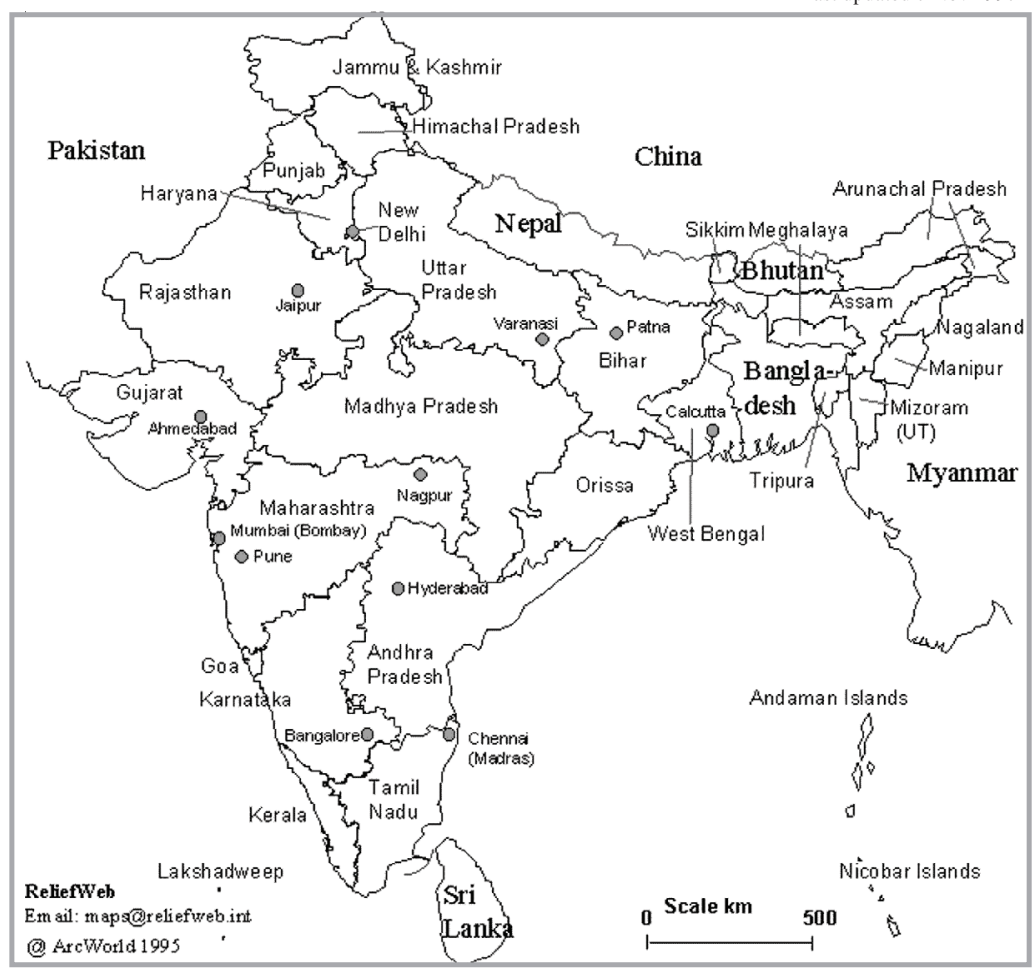

The boundaries and names shown and the designations used on this map do not imply official endorsement or acceptanceby the United Nations. These maps may be freely distributed.
Last updated 7 Nov 1997

seeks to analyze how the international legal norms for realization of the right get reconstructed and affect the process of realization of the right by women even when 'enabling' factors are facilitated by the state.

\section{Methodology}

While the above analysis can be made in the context of the developing world in general, the scenario in India was found to present an interesting setting for the study. because, despite a long history of state-level action and initiatives with respect to fulfillment of the right, as many as $\mathbf{2 0 0}$ million women and men continue to lack sustainable access to water (FIAN 2004). The findings of this paper are built upon a qualitative analysis of insights from a first-hand ethnographic study in selected pockets of rural India, situated in the states of Madbya Pradesh (MP), West Bengal (WB), Bihar and Jharkhand.

The primary data was procured through a combination of two methods - first, mapping and identification of the key actors involved in the process of realization of the right, followed by in-depth fieldwork conducted in a total sample of 32 villages. Two kinds of water supply sources were focused - first, the handpumps, installed extensively under the government program in MP, Bihar and Jharkhand; and second, contamination mitigation technologies for fluoride removal in MP and arsenic removal in WB.

Fieldwork techniques such as participant observation, unstructured and structured interviews with key informants using openended questions, focus group discussions (FGD), and case studies were used for procuring data. The sample of informants was large those participating in FGDs and those interviewed numbered 149 men and 162 
women drawn from different caste/ethnic groups in the villages. Twelve FGDs were held of which five were specifically organized for women. Case studies from four villages were also collected. The data collected was organized to construct community and group-based profiles with details on women and water with respect to social norms, cultural beliefs and values, social dynamics and community-based technology management issues. These profiles were then analyzed to draw generalizations on the issues raised in the paper.

\section{State actions for implementing the human right to water in India}

As a signatory to the different human rights instruments, there have been consistent efforts on part of the state in India to promote universal access to the right. Article 21 of the Constitution guarantees the right to protection of life, within the scope of which the right to safe drinking water is recognized (FIAN 2004; Langford et al., 2004).

There have been attempts to promote the needs and interests of women as water users. The National Water Policy (MWR, 1987, 2002) recognizes the provision of adequate safe drinking water facilities in rural areas as one of the priority areas for action. Similarly, the National Policy on Empowerment of Women (DWCD, 2001) warrants special attention to the needs of women in the provision of safe drinking water within the accessible reach of households, especially in rural areas. Also the guiding principles adopted at the level of states, such as the Women's Policy in Madhya Pradesh (MP) (DrWCD, 1997) envisage the water needs of women as a key area of interest and proposes to ensure sources of safe drinking water in every rural settlement.

For translating the policy guidelines into action, a number of interventions have been designed and implemented. On the whole, the seriousness of the problem has been particularly recognized in rural areas, where provision of water supply has been organized as a high-priority 'mission' activity for more than five decades. Special initiatives have been taken to tackle the problems of severe water shortage (in arid zones) and groundwater quality (in areas with high fluoride and arsenic). Gender concern in these interventions may be traced to an early concern with women as the focal target group to be benefited through domestic water supply programs. This has involved recognition of women as domestic water managers to be facilitated through provision of new, improved, reliable and safe water sources close to home, most commonly the handpump. For addressing problems of quality, suitable community-based water treatment plants have been installed.

The oldest and most widespread program has been the Accelerated Rural Water Supply Program (ARWSP) initiated in its present form in 1972-73 and aiming at ensuring coverage of all rural habitations and especially the 'unreached' with access to safe drinking water (MRD, 2002). Women have been identified as the principal beneficiaries of ARWSP. Both physical accessibility and nondiscrimination are ensured in the program, with a clear priority for habitations of the scheduled castes (SC) and scheduled tribes (ST). The terms SC and ST imply categories mentioned in one of the schedules of the Indian Constitution. These categories are considered to be weaker sections of society whose interests need to be safeguarded and promoted. Socially, these groups are seen as occupying the lower rungs of the local hierarchy. While the SCs occupy the lowest positions in the local caste hierarchy, STs represent indigenous communities that are placed outside the caste system.

The program guidelines define the 'access' to safe water in the following terms: provision of 40 liters per capita per day (lpcd) of drinking water for human beings; with one handpump or stand post for every 250 persons; and availability of water source (either private or public) in the habitation or within 1.6 kilometers in the plains and 100 meters elevation in hilly areas. Potable water for humans is meant for meeting the following daily requirements: drinking, cooking, bathing, washing and ablution.

A habitation that does not fulfill the above criteria is recognized as 'not covered' while one where capacity of the water supply system ranges between $10 \mathrm{lpcd}$ to $40 \mathrm{lpcd}$ is categorized as 'partially covered'. Habitations that have a water source but are affected with quality problems are considered 'no safe source' habitations, at least for purposes of drinking and cooking. The 'not covered'/'no safe source' habitations are prioritized in provision of safe water 
sources and first priority is given to the ones inhabited exclusively by SC/ST or having larger SC/ ST populations of less than 100 .

\section{The right to water in rural India in practice}

As a follow-up on the actions initiated by the state, improved water supply sources have been provided all over rural India. Four-fifths of the rural population is reported to have access to sources of safe water through more than 3.5 million 'public' handpumps and over 100,000 piped water schemes (Planning Commission, 2002, Chakraborty, 2003). Government statistics show that out of a total number of 1,422,664 rural habitations in the country, 1,256,956 (88.4\%) habitations are fully covered with drinking water facilities while 147,791 $(10.4 \%)$ are partially covered (MRD, 2002). However, the present study shows that, even when handpumps and piped water schemes are introduced, there is still very unequal access to the water supply. Clearly, technical/engineering solutions alone cannot achieve access to safe water to a level that meets international obligations.

\section{Equitable exercise of the right?}

The program guidelines have set a numerical criterion for selecting installation sites - one safe water source for a population of 250 . Implementation of this guideline has led to installation of handpumps or water treatment plants within village boundaries but not all women actually enjoy access to these sources. Here it is important to note that the Indian rural society is heterogeneous and hierarchical, patterned along the caste system. Castes are mutually inter-dependent, and are ranked, named and endogamous social groups. Membership is determined by birth (Beteille, 1996).

There are well-defined rules of social interaction among the different castes. These rules define patterns of residence and sharing of resources, including space and water, which are guided by notions of purity and pollution. Consequently, a single water source within the village can be shared only by castes of similar ranking. The social dynamics among the castes in the local community are influenced by the principle of 'dominance'. Among the basic criteria determining dominance are higher position in caste hierarchy, numerical preponderance and sizeable ownership of village land (Srinivas, 1959). The dominant caste exercises control over the use and management of space and resources in its village and influences decisions affecting the lives of all the resident castes. Social patterns based on the principle of dominance also have an important bearing on inter-ethnic situations in mixed villages regarding access to and management of spaces and resources in the village by Scheduled Tribes and other religious minorities such as Muslims and Christians

Under ARWSP and other rural water supply programs, handpumps and other improved water supply sources have been largely installed in government/public lands such as along main roads, near schools, health centers, community halls, etc. Ease of access for technical teams is often cited as one of the reasons underlying such decisions. Also, a water source installed at a public spot is expected to be open for public access and use, when compared to one located on a private plot, thereby being more suitable for achieving the program objectives. However, these may be located in the territories of the traditional elite who belong to the upper castes. Consequently, social access to such improved water supply sources remains denied to the needy members of the community with serious consequences for realization of their right to water.

Out of 44 public handpumps installed in the villages of MP and Bihar, only 9 were found to be actually situated within the localities of SC, ST and other minority sections. Two case studies from the study area illustrate the extent of manipulation of the program criteria with significant implications for exercise of the right to water.

Case 1: In village Lamkana in MP, the only handpump was originally meant to benefit the SC women, but it was installed at a public place along the main village road next to the Brahmin locality. Brahmins are an upper caste who are also dominant in the village. For them the public handpump is only an additional source because most of their households are better off with private water sources, while the poor SC households that lack access to even a single source of safe water has been denied the right of access. Respecting the caste norms and following the prevailing social order, the SC women continue to 
draw water from their traditional water source - a distant well that poses additional hardships during the summer months when it generally dries up.

Case 2: In village Masarh in Bihar, a public handpump that was supposed to be located along the main village road near the localities of Kumhar and Koiri has been actually installed in front of a Rajput household who have virtually 'monopolized' its use as well as maintenance. Sharing of the handpump is limited to other neighboring Rajput households, while the intended beneficiaries, placed lower in the caste hierarchy with limited economic as well as water resources, continue to depend upon their old well because following the prevailing caste norms; they lack access to the social spaces and resources of the former.

These case studies illustrate that, while the program criteria have been ostensibly designed in a way that will ensure equitable access to the new source and hence ensure equitable exercise of the right, the intended beneficiaries still remain excluded. Women from other backward groups and minority sections were also excluded from these water sources.

\section{Water quality}

Attempts to provide access to safe drinking water show similar results. High fluoride concentrations were found in groundwater in 14 districts of MP. Fluoride removal plants have been installed in affected villages, with support from DANIDA and UNICEF. In Shivpuri, one of the affected districts, 24 villages have been identified as 'at risk'. The symptoms of fluorosis have been affecting the villagers for more than two decades, with women and children being worst affected. Many of the handpumps installed earlier and traditional wells are now known to be contaminated so fluoride treatment plants have been installed. These include 'mini-plants' attached to handpumps and 'major plants' that treat groundwater and supply the treated water through pipes. However, not all women and their families have been able to benefit from the new safe sources. Similarly, in WB, not all women have been able to draw benefits from the communitybased arsenic removal plants. The situation is illustrated through the two following case studies.

Case 3: In village Hathoda in MP, the public handpump with an attached mini-plant was meant to provide access to safe water for drinking and cooking to a section of the village population, by being located at a public place. However, the plant is actually located inside an upper caste locality where lower caste women have been denied access. The latter continue to depend upon their traditional well for all domestic purposes, though its water is also contaminated.

Case 4: In village Thanarpara in WB, Muslim women were denied access to the single arsenic removal plant installed near a Hindu temple in the village by Hindu women who are ethnically dominant. This happened even when all public handpumps in the area are known to contain arsenic concentrations well beyond the permissible limits. However, the problem was resolved later through intervention of more liberally oriented volunteers from the area who worked out a time schedule for use because the Hindu women were reluctant to share the source at the same time.

\section{Effective exercise of right?}

In rural communities, the mere provision of an improved water supply source has not necessarily led women to wholly adopt the new source for drinking and cooking. Rural women as the domestic water managers are the prime decision-makers about the selection of the source for domestic water use. Their concern with water may be described as much more elaborate and comprehensive than merely the question of access to convenient, reliable and sustainable sources located close to home. Their domestic water needs may be described as holistic, classified into five basic purposes, namely: drinking and cooking; washing and cleaning; bathing; and sacred and therapeutic use. Selection of the water source is guided by the consideration of certain primary water qualities defined within the framework of local cosmologies. Consideration of water qualities is then coupled with additional criteria like distance, accessibility and convenience.

In the case of water meant for drinking and cooking, four different physical properties are generally regarded as critical. Good quality water is generally expected to be colorless, odorless, sweet and fresh and these qualities, in turn, are seen as closely related to the local concepts of purity, health and hygiene. Salinity is undesirable, as saline water is believed to be unsuitable for cooking, besides posing 
taste problems and ineffectiveness in quenching thirst. Freshly drawn water is regarded as pure as well as safe on health grounds. Any water filled on the previous day may be taken for washing and bathing or discarded since stored water is regarded as stale and therefore unhealthy. Purity of water is generally perceived in two different senses: purity from the health perspective and purity for ritual use. Fresh water is generally believed to be pure from both perspectives due to minimal handling and risk of pollution. For drinking purposes, the attribute of purity is often combined with clarity and colorlessness as well, so that the resultant water is safe on health grounds. Generally, these considerations also extend to water used for cooking. Water should help cook food quickly and not change the original color of the food. The significance attached to cooking water quality has also been recorded in other Indian studies (Mukherjee, 1990).

In a sample of 18 villages, with 55 handpumps installed under the water supply program in MP, Bihar and Jharkhand, it was found that 24 were largely rejected for drinking and cooking on one or more of the above grounds. In these villages, women prefer to procure water from the traditional sources, largely wells even though the 'safety' of these sources may be doubtful.

Another study conducted in the arsenic-affected areas in West Bengal revealed that out of a total of 182 arsenic removal plants installed in 4 blocks for providing safe drinking water, water from as many as 99 plants does not match expected water qualities of the community (SOES, 2004). Problems with the use of water for drinking from the new arsenic removal plants and even from treated surface water supplied through taps was also recorded during this study, the most common reasons being change in taste and smell and unsuitability of the water for cooking. In WB, the commonly used traditional water source is the pond. Pond water is preferred for cooking because it is believed to make rice white when cooked, and maintains freshness for longer in the hot and humid climate. Treated groundwater from arsenic removal plants or the tapped surface water supply do not have these desireable properties for cooking so women have avoided the handpump water for cooking in many instances; though handpump water, especially from deeper sources, is used commonly for drinking.
The unsuitability of the water from fluoride treatment plants for drinking and cooking was recorded in MP during this study. In all such instances, enjoyment of the right to water remains ineffectively exercised because even when physical access to the sources supplying safe water is provided, consumption of safe water is not ensured for the concerned women and their families.

These observations indicate that many criteria are used by women in the selection of water sources. Criteria include water quality, distance, accessibility and convenience. As a result of the diversity of criteria determining the nature of water preferred for different domestic uses, women may actually depend upon more than one source. They may view the newly-installed public water sources as a good addition that actually fulfils only a part of their requirements. Installation of these safe public sources reduces the need to carry water from afar but the low level of acceptance of safe water sources remains an important concern for public health.

Complexities about women's choice of water sources for different purposes has also been noted such as in Bangladesh, Ethiopia, Indonesia, Mexico, Nepal, Nigeria, Sri Lanka and Thailand (Brismar, 1997; van Wijk-Sijbesma, 1985) and also in Zimbabwe (Cleaver 1998) and Sudan (Kinuthia, 1994).

\section{Conclusions}

On the basis of findings of the study, it emerges that translation of the international norms for exercise of the human right to water at the local level is by no means easy. Explicit recognition of the right on the international front may make no practical impact on the women's lives as domestic water managers because the right itself may be re-interpreted in the local communities by the rights-holders - both women and men - within the context framed by their social norms and cultural beliefs and practices. While equitable exercise of the right by all women is implied in the normative contents of the General Comment No. 15, factors such as caste, religion and class may actually hamper equitable exercise of the right. Even the right-holders themselves may not be motivated to act against the socio-cultural norms in practice. water sources hamper fulfillment of the right at their own end. 
The study amply demonstrates that mere adoption of a normative framework at the international level and adoption of national actions through policies and programs does not ensure that the right-holders will realize the right to water. Factors rooted in the socio-cultural context of the right-holding women have a formidable influence, leading to inequitable and ineffective exercise of the right.

With respect to the question of equitable exercise of the right, the case material illustrates that the women - especially those belonging to the social groups that have traditionally faced difficulties in enjoying their right to water through adequate access to convenient and safe sources of water - are yet to be reached even after decades of implementing rural water supply programs. Ironically, this reality remains overlooked as their habitations are officially recognized as 'covered' when implementation of the program is monitored. The social norms leading to such a situation are either unrecognized or overlooked.

With respect to effective exercise of the right, the study underlines the need to recognize the role of cultural perceptions, beliefs and practices in the process of using new resources that are provided to rural women by external agencies for the purpose of realizing their rights. The reality that rural women are active decisionmakers in their domestic arena is often overlooked.

The implications of the study are clear. The international bodies and national governments need to be sensitized to the local realities confronting the translation of international human right norms into practice. An analysis of the governmental and non-governmental approaches in the study areas indicates a belief that adoption of policies, programs and relevant technologies are the panacea for ensuring the right. The findings presented here imply that the adoption of simplistic measures of success, based only on technical/engineering solutions, are insufficient. Monitoring and evaluation indicators are needed that can reflect access and use of water in practice.

In summary, appropriate action at the local level that considers the socio-cultural context is essential for facilitating greater equity and effectiveness in realization of the right to safe water by rural women.

\section{Acknowledgements}

This paper is based upon findings of a research project funded by the Swedish International Development Agency (SIDA). The author is thankful to Mr. O.P. Singh for discussions and valuable inputs to the issues raised in this paper.

\section{Glossary CEDAW}

CRC

DWCD

DrWCD

ECOSOC

FIAN

ICF

ICWE

Ipcd

MRD

MWR

SC

ST

UNDP

UNESCO

WHO

WWC

\section{References}

Beteille, A. (1996) Caste. In A. Barnard and J. Spencer (Eds.), Encyclopedia of social and cultural anthropology. London, New York: Routledge.

Brismar, A. (1997) Freshwater and gender: A policy assessment. Background paper to the Comprehensive Assessment of the freshwater Resources of the World, Stockholm: Stockholm Environment Institute.

CEDAW (1979) United Nations Division for the Advancement of Women. Accessed on $14 \mathrm{Jan}$ 2008 at http://www.un.org/womenwatch/daw/ cedaw/

Chakraborty, P.K. (2003) Issues in technology transfer in rural water supply and sanitation 
sector. Retrieved on 03 November 2007 from http://ddws.nic.in/Data/Papers/paper1.htm.

Cleaver, F. (1998) Choice, complexity and change: Gendered livelihoods and the management of water. Agriculture and Human Values, 15, 293-299.

CRC (1989) Office of the High Commissioner for Human Rights. Accessed on 14 Jan 2008 at http:/ / www.unhchr.ch/html/menu3/b/k2crc.htm

DWCD (2001) National policy for the empowerment of women. New Delhi: Ministry of Human Resources Development, Government of India.

DWCD (1997) The Madhya Pradesh policy for women: Implementation and achievements, Bhopal: Government of Madhya Pradesh.

ECOSOC (2002) Substantive issues arising in the implementation of the International Covenant on Economic, Social and Cultural Rights. General Comment No. 15 (2002): The right to water. Geneva: United Nations.

FIAN (2004) Investigating some alleged violations of the human right to water in India. Report of the International Fact Finding Mission to India. Retrieved 16 January 2008 from www.fian.organisation/ resources/documents.

Goonesekere, S. (2008) A rights-based approach to realizing gender equality. Paper written in cooperation with UNDAW. Retrieved 10 January 2008 from http://www.un. org/ omenwatch/daw/news/ rights.htm.

ICF (2001) Conference Report. International Conference on Fresh Water. Bonn, 3-7 December 2001. Retrieved on 14 January 2008 from http:// www.water-2001.de/,

ICWE (1992) Development issues for the $21^{\text {st }}$ century: The Dublin Statement Report International Conference on Water and the Environment, January 1992. Dublin: ICWE.

Jolly, R. (1998) Water \& human rights: Challenges for the twenty-first century. Address at the Conference of the Belgian Royal Academy of Overseas Sciences, 23 March, Brussels.

Kinuthia, C. (1994) Gender and management of water resources in an environment of scarcity. Report of Workshop on Gender and Water Resources Management, Stockholm, 1-3 December 1993. Stockholm: SIDA.

Langford, M., Khalfan, A. Fairstein, C. and Jones, H. (2004) Source No. 8: Legal resources for the right to water. Geneva: COHRE.

Long, N. (1992) From paradigm lost to paradigm regained? The Case for an actor-oriented sociology of development'. In: N. Long \& A. Long (Eds.), Battlefields of knowledge. The Interlocking of theory and practice in social research and development. London and New York: Routledge.
MRD (2002) Annual report 2001-2002. New Delhi: Government of India.

MWR (1987) National water policy. New Delhi: Government of India.

MWR (2002) National water policy. New Delhi: Government of India.

Mukherjee, N. (1990) People, water and sanitation: What they know, believe and do in rural India. New Delhi: The National Drinking Water Mission, Government of India.

Nhalpo, T. (1995) Cultural diversity, human rights and the family in contemporary Africa: Lessons from the South African Constitutional debate. International Journal of Law and the Family, 9, 208.

Nyamu, C. (2000) How should human rights and development respond to cultural legitimization of gender hierarchy in developing countries? Harvard International Law Journal, 41, 381.

Nyamu-Musembi, C. (2002) Towards an actororiented perspective on human rights. IDS Working Paper 169.

Planning Commission (2002) Tenth five year plan 2002-2007. Delhi: Planning Commission, Government of India.

Scanlon, J., Cassar, A. and Nemes, N. (2004) Water as a buman right? Gland, Switzerland and Cambridge, UK: IUCN.

Skutsch, M. (1996) Conflict analysis in joint forest management: Incorporating gender components. Paper presented at the CERES seminar on Gender, Land use and Development. Leiden.

SOES (2004) Sixth report on arsenic removal plants. Part $A$ and $B$. Kolkata, India: School of Environmental Studies, Jadavpur University.

Srinivas, M. N., (1959) The dominant caste in Rampura, American Antbropologist, 61, 1-16.

Tomasevski, K. (1993) Women and human rights. London: Zed Books Ltd.

UNDP (2003) Millennium development goals: A compact among nations to end human poverty. Oxford: Oxford University Press.

UNESCO (2006) Water a shared responsibility UN World Water Development Report 2 (WWDR) Oxford: Berghahn Books.

VanWijk-Sijbesma, C. (1985) Participation of women in water supply and sanitation: Roles and Realities. Technical Paper 22, The Hague: International Reference Centre for Community Water Supply and Sanitation.

WHO (2003) The right to water. Health and human rights publication series No. 3. Paris: WHO.

WWC (2003) The third world water forum: Final report. Tokyo: Japan: Secretariat of the Third World Water Forum. 